\title{
Biodegradation of Diesel Oil by Yeasts Isolated from the Vicinity of Suape Port in the State of Pernambuco -Brazil
}

\author{
Rita de Cássia Miranda, Cynthia Silva de Souza, Edelvio de Barros Gomes, Roberta \\ Barros Lovaglio, Carlos Edison Lopes and Maria de Fátima Vieira de Queiroz Sousa* \\ Departamento de Antibióticos; Universidade Federal de Pernambuco; 50670-901, Recife - PE - Brazil
}

\begin{abstract}
The aim of this work was to investigate the potential of the diesel oil degrading yeasts to use them in bioremediation of areas contaminated by this pollutant. The cultures, identified as Rhodotorula aurantiaca UFPEDA 845 and Candida ernobii UFPEDA 862, were selected at the initial stage. In the course of the biodegradation assays, $\mathrm{C}$. ernobii degraded tetradecane, 5 methyl-octane and octadecane completely and decane (60.8\%) and nonane (21.4\%) partially whilst $\mathrm{R}$. aurantiaca presented degradation percentages of $93 \%$ for decane, $38.4 \%$ for nonane and $22.9 \%$ for dodecane.
\end{abstract}

Key words: Biodegradation, yeasts, diesel oil

\section{INTRODUCTION}

Strategies for controlling environmental contamination by petroleum and its derivatives have been the subject of various studies over the past three decades. When a spillage occurs the first action is to remove the oily phase by mechanical or by physical-chemical means through the application of surfactants to disperse the layer of oil. Bioremediation is an alternative that has been used to eliminate or minimise the effects of pollutants by using microorganisms which have biodegradation potential (Atlas, 1995a). Diesel oil is a medium distillate of petroleum containing: $\mathrm{n}$ alkanes, branched alkanes, olefins and small concentrations of aromatic polycyclic compounds (Baker and Herson, 1999).

The Suape port terminal in the State of Pernambuco in Brazil is used by important distributors of diesel oil. The study of the biodegradation of fuels by native microorganisms is of extreme ecological importance, as the nearby beaches are subject to contamination by pollutants coming from the port complex. The objective of this work was to investigate the potential of the diesel oil degrading yeasts to use them in bioremediation of contaminated areas.

\section{MATERIALS AND METHODS}

\section{Selection Test}

Twenty-three strains of yeast, isolated from samples polluted by petroleum derivatives, collected from the Barra Lagoon, near the Suape port terminal, were evaluated for biodegradation of diesel oil.

Hanson et al (1993) method was used for selection of the strains. This method consisted of incorporating into the medium an electron

\footnotetext{
${ }^{*}$ Author for correspondence
} 
acceptor such as 2,6-dichlorophenol-indophenol (DCPIP) to test the ability of the microorganism to utilize the hydrocarbon substrate by observing the colour change of DCPIP from blue (oxidized) to colourless (reduced). Each well in a microtitre plate was filled with $250 \mu \mathrm{L}$ Büshnell-Haas (BH) medium, $10 \mu \mathrm{L}$ of diesel oil and $25 \mu \mathrm{L}$ of each microbial suspension standardised at $10^{8} \mathrm{CFU} / \mathrm{mL}$.

\section{Identification of the Isolates}

The selected yeasts were identified by their macroscopic, microscopic and physiological characteristics, as described by Lodder, (1970); Kreger-Van Rij, (1984) and Barnett et al., (1990).

\section{Acclimatation}

The selected strains were initially submitted to acclimatation by varying the concentration of diesel oil from 2 to $12 \%$ for a period of 20 days, before being used in the biodegradability tests.

\section{Biodegradation Assay}

The biodegradation assay was carried out over 15 days in six Erlenmeyer flasks of $500 \mathrm{~mL}$ (corresponding to $0,3,6,9,12$ and 15 days of experiment, respectively) each flask containing $12 \mathrm{~mL}$ of diesel oil, $68 \mathrm{~mL}$ of the Bushnell Haas medium containing $\mathrm{KH}_{2} \mathrm{PO}_{4}(1 \mathrm{~g}), \mathrm{K}_{2} \mathrm{HPO}_{4}(1 \mathrm{~g})$, $\mathrm{NH}_{4} \mathrm{NO}_{3}(1 \mathrm{~g}), \mathrm{MgSO}_{4} 7 \mathrm{H}_{2} \mathrm{O}(0,2 \mathrm{~g}), \mathrm{FeCl}_{3}(0,05 \mathrm{~g})$, $\mathrm{CaCl}_{2} 2 \mathrm{H}_{2} \mathrm{O}(0,02 \mathrm{~g}), \mathrm{H}_{2} \mathrm{O}$ destilated 1L (Atlas, $1995 \mathrm{~b}$ ) and $20 \mathrm{~mL}$ of acclimated inoculum under nonaseptic conditions. One sample from each assay was collected at three days intervals. No experiment replication was performed in the course of the assays. The $\mathrm{pH}$ and the biomass were measured while the evaluation of the biodegradation of the hydrocarbons of diesel oil was carried out only at the end of 15 days using gas chromatography connected to mass spectrometry.

\section{Biomass Measurement}

The biomass was measured as a dry weight. Aliquots of $20 \mathrm{~mL}$ were filtered through a microbiological membrane $(0.45 \mu \mathrm{m})$ and dried overnight $(12 \mathrm{~h})$ at $80^{\circ} \mathrm{C}$.

\section{Chemical Analysis}

Chromatographic and spectrometric analyses were performed by GC-MS (Shimadzu ${ }^{\mathrm{TM}}$, Model 17A/QP5050A) using a DB-5 chromatographic column $(5 \%$ diphenyl and $95 \%$ dimethylpolysiloxane) of size $30 \mathrm{~m} \times 0.25 \mathrm{~mm} \times$ $0.25 \mu \mathrm{m}$. The temperature was programmed to vary linearly from $40^{\circ} \mathrm{C}$ to $270^{\circ} \mathrm{C}$ at the rate of $10^{\circ} \mathrm{C} \min ^{-1}$ and maintained for $22 \mathrm{~min}$. Helium was the carrier gas and the interface temperature was $280^{\circ} \mathrm{C}$. Injection of samples and control into a GC-MS system was carried out in triplicate. The highest resolution chromatographic peaks were scanned to find their corresponding massfragmentation profile. Compounds were characterized based on similarities between their mass spectrum and those presented by Wiley ${ }^{\mathrm{TM}}$ Compounds Library. Control peak-areas were used as a point of reference for the remaining compounds (100\%) in the untreated system. Sample peak-areas were reported as a percentage of control peak-areas.

\section{RESULTS AND DISCUSSION}

\section{Selection Test}

Of the 23 strains tested, only two (UFPEDA 845 and UFPEDA 862) were selected because they completely discoloured the culture medium after 16 and $24 \mathrm{~h}$ of incubation at $30^{\circ} \mathrm{C}$, respectively. The other strains caused the culture medium to become colourless after periods of $48 \mathrm{~h}(8 \%)$ and $72 \mathrm{~h}$ (84\%). Hanson et al. (1993), using a microtitre plate to test the potential of five isolated strains of bacteria to degrade crude oil, selected two isolates because they caused a change in the colour of the culture medium containing the DCPIP indicator after $12 \mathrm{~h}$ of incubation, while the other isolates responded less quickly to the biological oxidation, showing a change in the DCPIP indicator only after $24 \mathrm{~h}$ of incubation at $35^{\circ} \mathrm{C}$. Another criterion used to determine the most probable number of microorganisms with the potential to degrade crude oil was suggested by Brown and Braddock (1990) who verify the rupture of the oily surface of the culture medium in microtitre plates. The rupture was attributed to the production of biosurfactants at the beginning of the biodegradation process.

\section{Identification of Yeasts}

The UFPEDA 845 strain was identified as Rhodotorula aurantiaca and the UFPEDA 862 strain as Candida ernobii. Komagata et al. (1964), investigating 500 yeasts, found that 56 species assimilated hydrocarbons, most of them belonging to the Candida genus. Ahearn et al. (1971) cited 
other genera that have the capacity to assimilate hydrocarbons, such as: Rhodosporidium, Rhodotorula, Saccharomyces, Sporobolomyces, Trichosporium and Cladosporium. Bento and Gaylarde (2001) suggested that the yeasts Rhodotorula glutinis and Candida silvicola were the main contaminants in diesel oil storage tanks.

\section{Biodegradation Assays}

Before proceeding to the biodegradation assays, the two selected strains were first acclimated using increasing concentrations (from $2 \%$ to $12 \%$ ) of diesel oil as the only carbon and energy source for 20 days. During the acclimatation period, both selected yeast strains presented different growth, resulting in different initial biomass concentration in the biodegradation assays $(0,3 \mathrm{~g} / \mathrm{L}$ for $R$. aurantiaca UFPEDA 845 and $0,05 \mathrm{~g} / \mathrm{L}$ for $C$. ernobii UFPEDA 862). According to Alexander
(1994), on acclimatation, the level of assimilation of the pollutant may be higher or lower, but, if further pollutant is added, degradation of this increment will occur after a short or practically non-existent period of acclimatation. Several authors have pointed out that the adaptation of the microbial culture to the pollutant is preponderant in the biodegradation process. Microorganisms isolated from environments with a history of pollution by petroleum hydrocarbons have higher ability to degrade such pollutants (Englert and Kenzie, 1993; Kilbane II et al., 2000).The biodegradation assays with $12 \%$ of diesel oil, carried out with the two selected strains (Rhodotorula aurantiaca UFPEDA 845 and Candida ernobii UFPEDA 862), were accompanied by measuring the $\mathrm{pH}$ and biomass over a period of 15 days, as seen in Figs. 1 and 2.

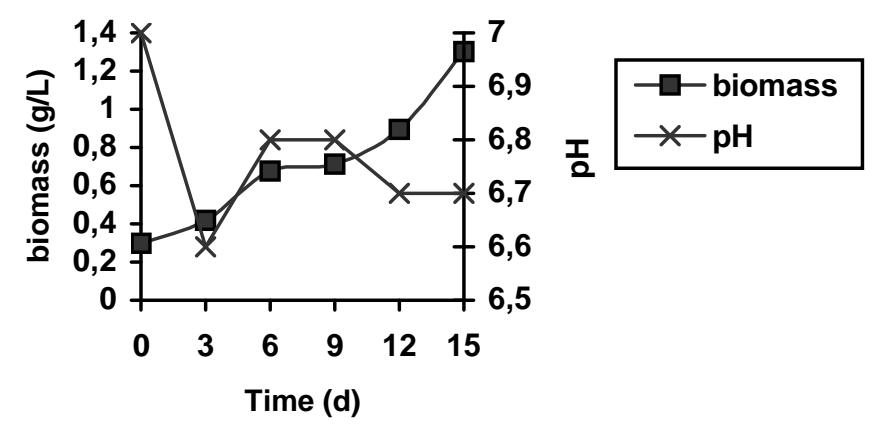

Figure 1 - Biomass and $\mathrm{pH}$ of Rhodotorula aurantiaca UFPEDA 845 over 15 days of degradation using $12 \%$ diesel oil as carbon source.

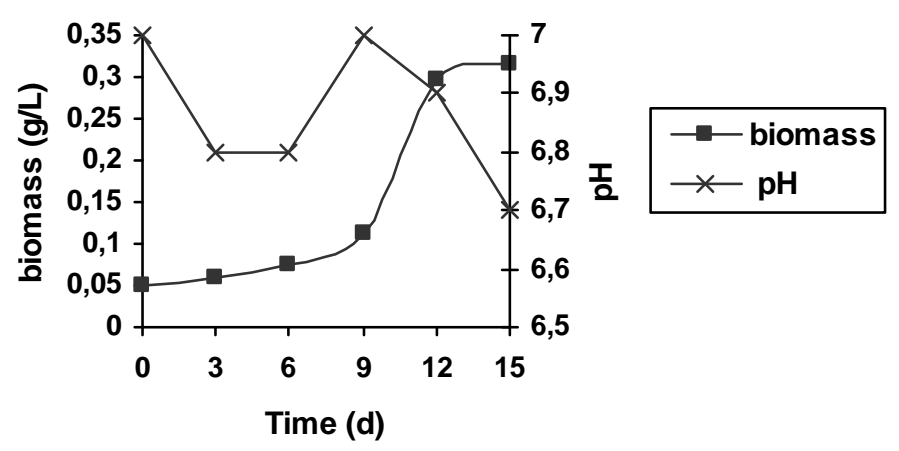

Figure 2 - Biomass and $\mathrm{pH}$ of Candida ernobii UFPEDA 862 over 15 days of degradation using $12 \%$ diesel oil as carbon source. 
It should be noted that both strains showed $\mathrm{pH}$ values in the range of 6.6 and 7.0, near to neutrality, over the fifteen day assay, with a coincidental decrease on the $\mathrm{pH}$ values on the third day, which indicate greater production of organic acids as intermediate products of the biodegradation of the hydrocarbons. Leahy and Colwell (1990) observed that $\mathrm{pH}$ values between 6.0 and 8.0 were more appropriate to the action of microorganisms that degraded petroleum, although fungi were more tolerant of acidic conditions. Figs. 1 and 2 showed that there was an increase in the biomass concentration in both cultures of yeast. Fig. 1 showed that the biomass of $R$. aurantiaca UFPEDA 845 initially grew from 0.3 to $0.7 \mathrm{~g} / \mathrm{L}$ over the first six days, then stabilized for three days, and then grew significantly (from 0.7 to $1.3 \mathrm{~g} / \mathrm{L}$ ) until the end of the experiment, suggesting a diauxic behaviour, which means two clear phases of growth separated by a period of adaptation to the new nutritional conditions. Given the great diversity of hydrocarbons in the diesel oil, it can be supposed that constituent of the oil responsible for the growth of the $R$. aurantiaca in the first phase was probably not that used in the second phase of growth. Fig. 2 showed that the $C$. ernobii UFPEDA 862 exhibited slow growth up to the ninth day, but the biomass subsequently grew exponentially until the twelfth day, maintaining by the end of the 15 days a maximum concentration of $0.33 \mathrm{~g} / \mathrm{L}$, which is four times less than that attained by the $R$. aurantiaca UFPEDA 845 in the same time (1.3 g/L). Espírito-Santo (2002), using agitated flasks with the Bushnell-Haas medium containing $5 \%(\mathrm{v} / \mathrm{v})$ concentration of diesel oil, applied $10^{7} \mathrm{CFU} / \mathrm{mL}$ of inocula and observed a maximum of $10^{8} \mathrm{CFU} / \mathrm{mL}$ of fungi after 8 days, decreasing shortly thereafter to $10^{5} \mathrm{CFU} / \mathrm{mL}$, at the end of the 20-day experiment. The evaluation of the biodegradability of diesel oil by the selected cultures was carried out only at the end of the assay (15 days), whose results in terms of percentages of degradation of aliphatic hydrocarbons present in the diesel oil are shown in Fig. 3.

Of the investigated aliphatic hydrocarbons, 10 were examined with greater precision by the methodology used in the GC-MS system. The yeast $R$. aurantiaca UFPEDA 845 showed higher percentages of degradation for decane, nonane and dodecane $(93.0 \%, 38.4 \%$, and $22.9 \%$, respectively) while $C$. ernobii UFPEDA 862 completely degraded tetradecane, 5-methyl-octane and octadecane, and partially decane $(60.8 \%)$ and nonane $(21.4 \%)$.

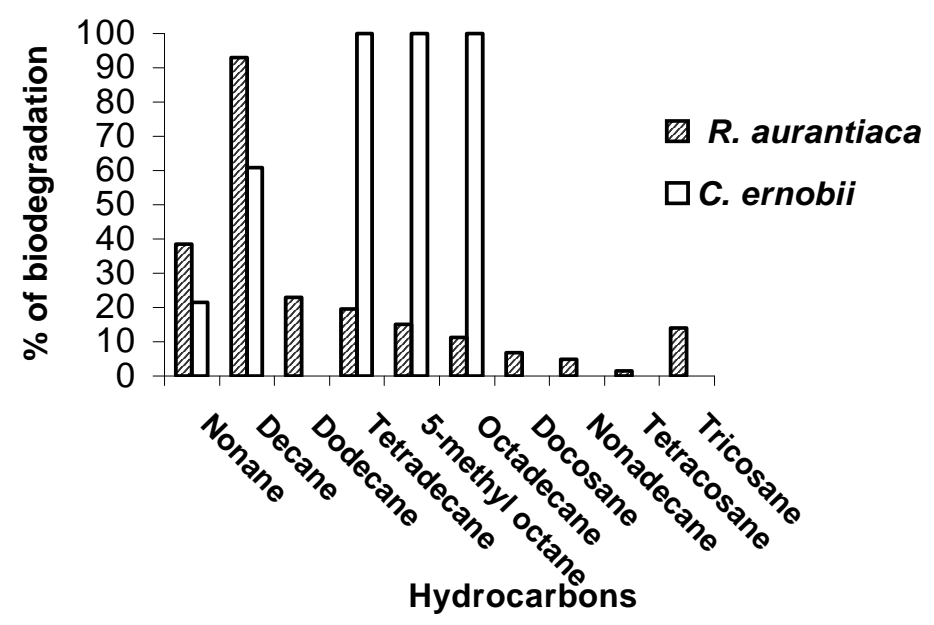

Figure 3 - Percentage of degradation of diesel oil hydrocarbons after 15 days of biodegradation assays, using the yeasts Rhodotorula aurantiaca UFPEDA 845 and Candida ernobii UFPEDA 862 with $12 \%$ of the oily source. 
Richard and Vogel (1999), cultivated a consortium using diesel oil as the only source of carbon and energy and reported degradation of $90 \%$ of the fuel oil after 50 days of cultivation. Ruberto et al. (2003), working with a nutritional C:N:P ratio of 100:12:3, after 50 days of the process, obtained reductions in the mean concentration of hydrocarbons present in diesel oil of 35\% (indigenous microflora) and 65\% (psychrotolerant strain) compared to the initial concentration. Suparna et al. (2004), using diesel oil as the sole source of carbon and energy, tested the diesel oil biodegradation ability of cultures isolated from Arabian sea sediments. Under aerobic conditions, $39 \%$ loss of fuel was observed over 8 days where $80 \%$ of the loss was due to aliphatic constituents, and under anoxic nitrate reducing conditions the rate and extent of degradation was significantly lower (18\%).

The results obtained for the yeasts $R$. aurantiaca UFPEDA 845 and C. ernobii UFPEDA 862 can be used to draw up a bioremediation protocol involving the optimisation of parameters, such as biostimulation and bioaugmentation for the recuperation of areas contaminated by diesel oil as well as by other oily sources from petroleum.

\section{ACKNOWLEDGEMENTS}

The authors would like to thank FINEP/CTPetro for financial support during this research.

\section{RESUMO}

O objetivo deste trabalho foi investigar a potencialidade de leveduras que degradam óleo Diesel, visando aplicação em processo de biorremediação de áreas impactadas pelo referido poluente. As culturas, identificadas como Rhodotorula aurantiaca UFPEDA 845 e Candida ernobii UFPEDA 862, foram as selecionadas na etapa inicial. Quanto aos ensaios de biodegradabilidade, a levedura Candida ernobii UFPEDA 862 degradou totalmente: tetradecano, 5 metil-octano e octadecano, e parcialmente decano $(60,8 \%)$ e nonano $(21,4 \%)$, enquanto que a Rhodotorula aurantiaca UFPEDA 845 apresentou percentuais de degradação de $93,0 \%$ para decano, $38,4 \%$ para nonano e $22,9 \%$ para dodecano.

\section{REFERENCES}

Ahearn, D. G.; Meyers, S. P.; Standard, P. G. (1971), The Role of Yeasts in the Decomposition of Oils in Marine Environments. Dev. Indust. Microbiol. 12, 126-134.

Alexander, M. (1994), Environmental Effects. InBiodegradation. and Bioremediation. 2 ed. Academic Press, New York, pp. 269-298.

Atlas, R. M. (1995a), Bioremediation of Petroleum Pollutants. Internat. Biodeterior. and Biodegrad.., 317- 327.

Atlas, R. M. (1995b), Handbook of Media Environmental Microbiology, CRC Press, London

Baker, K. H.; Herson D. S. (1999), .Bioremediation. McGraw-Hill, New York, Inc. p-375.

Barnett, J.A.; Paine, R.W.; Yarrow, D. (1990), Yeasts: Characteristics and Identification. University Press, Cambridge.

Bento, F. M.; Gaylarde, C. C. (2001), Biodeterioration of stored diesel oil: Studies in Brazil. Internat. Biodeteriorat. and Biodegradat., 47, 107-112.

Brown, J. E.; Braddock, J.F. (1990), Sheen Screen, a Miniaturized Most-Probable-Number Method for Enumeration of Oil-Degrading Microorganisms. Appl. and Environ. Microbiol., 56, 3895-3896.

Englert, C. J.; Kenzie, E. J. (1993), Bioremediation of Petroleum Products in Soil. API, 40, 111-129.

Espírito-Santo, L. S. (2002), Biodegradabilidade de óleo Diesel por microrganismos nativos da areia da praia de Suape - PE e predição de um modelo relacionado ao derramamento do poluente. Dissertação de Mestrado, Universidade Federal de Pernambuco, Pernambuco, Brasil.

Hanson, K. G.; Desai, D.; Desai, A. J. (1993), A rapid and simple screening technique for potential crude oil degrading microorganisms. Biotechnol. Techn., 7, 745-748.

Kilbane II, J. J.; Ranganatan, R.; Clevland, L.; Kayser, J. K.; Ribeiro, C.; Linhares, M. (2000), Selective Removal of Nitrogen From Quinoline and petroleum by Pseudomonas ayucida IGTN9m. Appl. and Environ. Microbiol., 66, 688-693.

Kogamata, K.; Nakase, T.; Katsuya. (1964), Assimilation of Hydrocarbons by Yeasts. I Preliminary Screening. Journ. Gen. Microbiol. 10, 323-331.

Kreger-Van Rij, N.J.W. (1984), The Yeast: A Taxonomic Study, 3 ed. Elsevier Sci. Publication, Amsterdam.

Leahy, J. G.; Colwell, R. R. (1990), Microbial Degradation of hydrocarbons in the Environment. Microbiol. Rev., 54, 305-315.

Lodder, J. (1970), The Yeast: A Taxonomic Study. North Holland Publishing Company, Oxford. 
Richard, J.Y.; Vogel, T.M. (1999), Characterization of Soil bacterial consortium capable of degrading diesel fuel. Internat. Biodeteriorat. and Biodegradat., 44, 93-100.

Ruberto, L.; Vasquez, S., C.; Cormack, W. P. M. (2003), Effectiveness of the Natural Bacterial flora, Bioestimulation and Bioaugmentation on the Bioremediation of Hydrocarbon Contaminated Antarctic Soil. Internat. Biodeteriorat. and Biodegradat., 52, 115-125.

Suparna, M.; Sheeja, J.; Gita, M.; Avinash, V. (2004), Biodegradation of Diesel Oil by an Arabian Sea Sediment culture Isolated from Vicinity of an Oil Field, Biores. Technol., 95, 281-286.

Received: March 24, 2005; Revised: January 27, 2006; Accepted: September 12, 2006. 